\title{
invotec
}

The International Journal of Technical and Vocational Education

UPI JOURNAL

Available online at http://invotec.fptk.upi.edu

\section{Green and Sustainable Development for TVET in Asia}

\author{
R. B. Mustapha
}

Department of Engineering Technology, Faculty of Technical and Vocational Education, Sultan Idris Education University

\section{ARTICLE INFO}

Article history:

Received 29 July 2015

Received in revised form 12

November 2015

Accepted 13 November 2015

Available online 11 December

2015

Keywords:

Green paradigm

Suistanable development

Human Resource

Development

TVET

Asia

Corresponding author:

drramlee@yahoo.com

\section{A B S T R A C T}

Green paradigm is emerging in Asia. In order to achieve sustainability, embracing green paradigm is critical. The growing significance of sustainability is having a major impact on business, industry, and society as a whole. Hence, preparing the future workforce for the coming green economy is a challenging task for many Asian countries especially in Technical and Vocational Education and Training (TVET) in the post-2015 agenda. As a ground work, transforming TVET in Asia to meet the challenges of the green economy for the purpose of sustainability should begin now. The aim of this paper is to map the sustainable development in terms of green mindset, lifestyle, economy, education, training, employability and sustainability in selected Asian countries. A country's quantum leap or leap-frogging in sustainable economy is dependent of its transformation of human resources especially in TVET sector. Thus, TVET should be transformed to fit the requirements of the sustainable green paradigm. The results posit the country's policies, best practices, and challenges toward green economy in order to achieve sustainable development. Finally, the implication of green paradigm on TVET system in selected countries in the Asia Pacific will be discussed.

\section{Introduction}

According to Maclean et al. (2013), Asia-Pacific region is huge and complex - be it geographical, socioeconomics or demographics. Islam and Chowdhury (1997) echoed Dixon and DrakakisSmith's (1993) earlier proclamation that the economies of East and Southeast Asia are becoming integrated into a broad Asia Pacific region. Literature indicates that the Asia Pacific region has experienced tremendous economic development over the past few decades. Ariff (1991) termed this phenomenon the Pacific factor. "A key 
element in the whole process is what may be termed the Pacific factor. The Pacific Basin has emerged as the most dynamic region and there are signs that the world activity is gravitating from the Atlantic to the Pacific" (p. 4). If Asia-Pacific continue to grow on its projected curve, it could by 2050, account for more than $50 \%$ of world's GDP (as compared to $27 \%$ in 2010), with a six-fold increase in per capita income comparable to European levels of today. Seven Asian nations - Japan, South Korea, China, India, Malaysia, Thailand and Indonesia - are projected to account for $87 \%$ of the total GDP growth in Asia and almost $55 \%$ of the global GDP growth between 2010 and 2050 (Asian Development Bank, 2011). Estimated 63\% of the world's population is located in this region with wide differentiated GDP with some rich countries (such as Japan) and several poor countries (such as Bangladesh). The incidence of those living below the poverty line is as high as $40 \%$ is existed in a number of Asian countries (UNESCAP, 2011).

However, the region's geographical endowment suggests that a large proportion of its natural resources are vulnerable to environmental degradation. The region is the home to many small islands developing states (SIDS) most of which face the challenges of rough conditions as a result of climate change. In a context where achieving harmonious development is critical, several Asian countries have set poverty alleviation target and sustainable development goals (SDGs) as a top priority. However, it is difficult to ignore how countries are overcoming poverty, social and economic challenges and environmental vulnerability. The activities of regional and sub-regional blocs in the Asia Pacific, most notable of which is the transition of the ASEAN bloc into ASEAN Economic Community 2015 (ACE 2015) set the agenda for ASEAN countries to harness their potential of becoming more competitive supported by a strong workforce. Several critical issues emerged from literature and critical reports on green economy and its impact on countries' competitiveness. However, little was discussed about the impact of green economy on TVET. Thus, the purpose of this critical review is to examine critical perspectives on the impact of green paradigm on TVET for continuous harmonious development.

\section{Challenges Of Green Development In Asia}

A number of Asia and the Pacific countries have recorded significant growth rates that have been much admired, as they not only contributed to reducing poverty in the region but also to a shift in the balance of economic power in Asia. A number of Asian countries are reaching and surpassing middle income levels. The high growth rates are accompanied by concerns regarding the environmental sustainability as the region also recorder marked by adverse trends of reduced air and water quality, depleting natural resources and threats to biodiversity. In 2005, the Asia and Pacific required three times more resources than the rest of the world (Jagannathan, 2013). Asia's use of raw materials reached a world-leading 35 billion tons and can reach a figure of 80 billion tons by 2050. Asia Pacific's share of global energy demand was about $35 \%$ in 2005 and expected to reach $50 \%$ by 2028 . Several reports pointed to Asia as being the largest source of carbon emissions from automobiles and industries. Thus, there is an urgent need for Asia and the Pacific region to consider using fewer resources to ensure the region's continued growth and sustainable development (Jagannathan, 2013). Today, one of the world's challenges is the greening of the economy. As the world's record of pollution and climate disasters via global warming at its peak, each country is asked to reduce its carbon emission and the Asian Development Bank estimates that the economic impact of climate change in Asia will be 2.5 times more severe than the global average by 2100 if carbon emissions continue at their current level (Maclean et al., 2013).

Based on Brundtland Report (1987) and World Commission on Environment and Development (1987), Sustainable Development (SD) is defined as a process for meeting human development goals while sustaining the ability of natural systems to continue to provide the natural resources and ecosystem services upon which the economy and society depend. Sustainable development ties together concern for the carrying capacity of natural systems with the social, political, and economic challenges faced by humanity. There is an additional focus on the present generations' responsibility to regenerate, maintain and improve planetary resources for use by future generations. In recent years, the concept of a "green economy" has become central to the international agenda. It is used to review and clarify the linkages between a green economy and sustainable development. The concept of a green economy does not replace sustainable development, but there is a growing recognition that achieving sustainability rests almost entirely on getting the economy right. There is no universal agreement on the definition of what a green economy entails. The working 
definition of UNEP describes a "green economy as one that results in improved human well-being and society equity, while significantly reducing environmental risks and ecological scarcities". In brief, a green economy can be thought of as one which is low carbon, resource efficient and socially inclusive. In a green economy, growth in income and employment should be driven by public and private investment that reduce carbon emissions and pollution, enhance energy and resource efficiency and prevent the loss of biodiversity and ecosystem. A similar, but broader definition is provided by the United Nation Economic and Social Commission for Asia and the Pacific (ESCAP), which states that a "green economy can be defined as an economy where economic prosperity can go hand in hand with ecological sustainability". In 2010 and 2011. Denmark and Sweden both top the green reputation in the Global Green Economy Index (GGEI) - solidifying their leadership position in the global green economy (see Table 2). Table 1 shows the Global Green Economy Index is an in-depth analysis of national green performance/reputation of 27 countries judged by expert practitioners based on national data. Elements in the GGEI include: green leadership, green policy, clean technology investment, and green/sustainable tourism. Table 2 shows the top 10 green countries gained reputation in managing green economy and governance.

Table 1

Global Green Economy Index

\begin{tabular}{|c|c|c|}
\hline Category & Indicators & Descriptions \\
\hline \multirow[t]{4}{*}{ Leadership } & Head of State & Advocacy for green issues \\
\hline & Media Coverage & Positive media coverage of national green economy \\
\hline & International Forum & National position and statements in international forum \\
\hline & International Aid & Commitment to sustainability in aid programs \\
\hline \multirow[t]{4}{*}{ Policy } & Commitment to Renewal Energy & Shares of renewables in total energy utilization \\
\hline & Clean Energy Policy & Adoption of best practice policies \\
\hline & Emissions & Index of national emission \\
\hline & Renewal Energy Goals & Progress toward renewable goals \\
\hline \multirow{4}{*}{$\begin{array}{l}\text { Cleantech } \\
\text { (Clean } \\
\text { Technology) } \\
\text { Investment }\end{array}$} & Investment Volume & Recent investment in clean energy \\
\hline & Cleantech Commercialization & Business climate for cleantech commercialization \\
\hline & Cleantech Innovation & Business climate for clentech innovation \\
\hline & Investment Facilitation & Strength of green investment \\
\hline \multirow{3}{*}{$\begin{array}{l}\text { Sustainable } \\
\text { Tourism }\end{array}$} & Travel \& Tourism Competitiveness & Country competitiveness in sustainable touris \\
\hline & Accreditation Scheme & Presence and strength of national schemes \\
\hline & Ministry Evaluation & Strength of green tourism promotion \\
\hline
\end{tabular}

Source: Dual Citizen (2012) 
Table 2

Top 10 countries with green reputation in 2012

\begin{tabular}{ll}
\hline Ranking & Countries \\
\hline 1 & Denmark \\
2 & Germany \\
3 & Italy \\
4 & Sweden \\
5 & UK \\
6 & New Zealand \\
7 & Spain \\
8 & Norway \\
9 & Brazil \\
10 & Australia \\
\hline
\end{tabular}

\section{The Drivers Of Sustainable Development In The Asia Pacific}

To nurture sustainable development, it may not just involve changing thinking and lifestyle but also changing a culture. Prime movers can be observed in the efforts to address environmental issues. The transitions to low-carbon economies and societies is one of them. Countries are increasingly focusing on abating the further degradation of the environment and restructuring economic and social development. They are looking to achieve sustainability, market competition, and employment, sustainable transformations and mitigation of long-term climate change impact. The ILO has reported extensively on the drivers of change at the global level, citing environmental changes, shifts to environmental policies, technology and innovations and changes in the market and consumer habits. These drivers have an impact on the need for skills as economies becomes more green (Strietska-Ilina, 2011). Achieving low carbon world is manifest in three significant benefits: reduced emissions, higher productivity of the economy, and inclusive growth. According to Jagannathan (2013), the main aspects of green transition include the following:

(a) Transition to greater use of energy from renewable sources - these could include solar, wind, biomass, geothermal, ocean, hydropower, landfill gas and municipal solid waste.

(b) Transition to greater use of products and services that increase energy efficiency - these include energy-efficient equipment, appliances, vehicles, as well as products and services that improve the energy efficiency of buildings and the efficiency of energy storage and distribution, such as smart grid technologies

(c) Transition to greater use of processes that reduce/remove pollution and green-house gas emission and transition to recycling and reuse.

(d) Transition to greater use of products and services that conserve natural resources - these include organic agriculture, sustainable forestry, land and soil management, soil and wildlife conservation and water management.

(e) Transition to greater use of products and services that comply with environmental regulations and standards. 
Several countries in Asia Pacific are building solid policy foundations toward achieving green lifestyle. The Clean Development Mechanism (CDM) is a market-based mechanism under the Kyoto Protocol used by countries to meet commitment to reduce their greenhouse gas emissions. In terms of renewal energy, the UN target of doubling the share of the world's green energy supplied by renewal sources from $15 \%$ to $30 \%$ by 2030 (Jagannathan, 2013). According to Jagannathan (2013), several nations are formulating regulations, standards, and targets for producing renewal energy. China has set of reaching $15 \%$ of its energy supply from renewal sources by 2020 and the EU has put a goal of $20 \%$ for the same period. The United States plans to generate 35 billion gallons of alternative fuels in 2017. Some countries are offering incentives and subsidies to encourage its citizen and companies to use renewal energy.

Asia has joined other regions of the world to put in place measures for climate change mitigation and adaption. Global commitments to climate change have contributed to "greening" of economies and corporations. This lead up to the recent Rio+20 Conference on sustainable development spurred a spate of initiatives and actions to reinforce green paradigm that integrates environmental-friendly and sustainability features. With right policies and incentives, "greening economy" can be made viable and profitable in the long run (ADB, 2012b). According to ILO Report (2012), transformation to the green economy could generate 15-60 million additional jobs over the next two decades and lifts tens of millions of workers out of poverty. Green paradigm is critical in preventing environment degradation, biodiversity loss, and unsustainable natural resources use (OECD, 2010). There are ongoing discussions on the development of internationally agreed

goals the incorporate sustainable principles, and it is expected that the Millennium Development Goals (MDGs) that have established targets until 2015 will be replaced or complemented with Sustainable Development Goals. The transition toward green economy will require new indicators that go beyond income disparities.

Education and training have a crucial role to play in the successful transition of economies to green and clean development that is conducive to inclusive growth. Yet, there is no systematic and comprehensive approach to linking education and training policies with climate change adaptation, mitigation, and Green. Article 6 of the UN Framework Convention and Climate Change (UNFCCC) attributed only a minor role in education and training in terms of awareness to win public support for climate policies. Adequately trained and skilled workers would facilitate faster technology absorption and could assist industry to adopt green technologies. The training of the "green-collar" workers is necessary to provide required workforce to meet the requirements of green economy. Thus, the curricula of schools, universities and training institutes need to be revised in order to incorporate relevant "green" courses and programs. Investing in R \& D in green technologies are deemed necessary. The far-reaching influence of education and training in advancing green technologies is expected in the future.

\section{Green Professionals}

The implementation of climate change commitments is leading to new skill requirements. While some areas require altogether new skills, a large number of existing occupations require additional skills and competencies in the context of efforts to move toward a low-carbon world. New types of skills and competencies will need to be incorporated into existing occupational profiles of the workforces. Asia Business Council (2009) predicts that the number of green jobs created by 2030 could reach 100 million worldwide, which is estimated at $2 \%$ of the future workforce. Roughly, Asia could have 50 million green jobs, and many jobs in the existing industries would require green skills as manufacturing sector may change their production processes using clean technology or they may develop green products (Maclean et al., 2013). Thus, there is need for developing new "green" training curricula. Vocational and technical training will be critical in building the necessary skill base for green jobs. Link with education and training a higher level through the tertiary sector is required. Comprehensive green skill standards and certification system need to be developed. Benchmarking standards, establishing protocols for standards in new green jobs, existing but "transformed" jobs and in green processes will require participation of higher education institutions. 
Table 3

Knowledge and skills to support green initiatives

\begin{tabular}{|c|c|c|c|}
\hline Objectives & Enabling & \multicolumn{2}{|r|}{ Verifying } \\
\hline $\begin{array}{l}\text { Expanding low-carbon } \\
\text { and green approaches } \\
\text { to growth }\end{array}$ & $\begin{array}{l}\text { Environmental } \\
\text { climate change }\end{array}$ & $\begin{array}{l}\text { Skills for implementing } \\
\text { environment services }\end{array}$ & $\begin{array}{l}\text { Knowledge of green } \\
\text { accounting and carbon } \\
\text { foot printing }\end{array}$ \\
\hline $\begin{array}{l}\text { Accelerating energy } \\
\text { efficiency solutions }\end{array}$ & Regulations awarness & $\begin{array}{l}\text { Skills to commercialize } \\
\text { environmental products }\end{array}$ & $\begin{array}{l}\text { Knowledge } \\
\text { greenhouse } \\
\text { accounting }\end{array}$ \\
\hline $\begin{array}{l}\text { Increasing adoption of } \\
\text { clean energy solutions } \\
\text { and renewable energy }\end{array}$ & $\begin{array}{l}\text { Awarness of behavior } \\
\text { changes } \\
\text { consumption patterns to } \\
\text { support low carbon } \\
\text { growth }\end{array}$ & $\begin{array}{lr}\text { Capabilities } & \text { for } \\
\text { developing } & \text { technology } \\
\text { options and technology } \\
\text { absorption }\end{array}$ & $\begin{array}{l}\text { Knowledge certified } \\
\text { carbon accounting } \\
\text { Knowledge and license } \\
\text { for eco-labeling }\end{array}$ \\
\hline $\begin{array}{l}\text { Increasing energy } \\
\text { security and assuring } \\
\text { energy for all }\end{array}$ & $\begin{array}{l}\text { Knowledge of choice of } \\
\text { appropriate technology }\end{array}$ & $\begin{array}{l}\text { Abilities to implement } \\
\text { eco-friendly services suc } \\
\text { as eco-villages and } \\
\text { smart electricity grids }\end{array}$ & $\begin{array}{l}\text { Knowledge and license } \\
\text { for ISO } 14001 \text { and ISO } \\
50001 \text { certification }\end{array}$ \\
\hline $\begin{array}{l}\text { Expanding } \\
\text { environmentally friendly } \\
\text { products and services }\end{array}$ & $\begin{array}{l}\text { Technology absorption } \\
\text { and adaption capabilities }\end{array}$ & $\begin{array}{l}\text { Technical and } \\
\text { managerial skills to } \\
\text { implement low carbon } \\
\text { production } \\
\text { processing systems }\end{array}$ & $\begin{array}{l}\text { Knowledge for energy } \\
\text { audits }\end{array}$ \\
\hline & $\begin{array}{l}\text { Product development } \\
\text { capacities }\end{array}$ & $\begin{array}{l}\text { Skilss to implement } \\
\text { business models that } \\
\text { meet the triple bottom } \\
\text { line-financial, social and } \\
\text { environmental }\end{array}$ & $\begin{array}{l}\text { Knowledge for certifying } \\
\text { legal compliance with } \\
\text { regulations }\end{array}$ \\
\hline & $\begin{array}{l}\text { Environmental services } \\
\text { and advisory } \\
\text { capacities }\end{array}$ & & $\begin{array}{l}\text { Knowledge of protocols } \\
\text { for MRV requirements }\end{array}$ \\
\hline
\end{tabular}

MRV = measurement, reporting and verification

Source: Jagannathan (2013)

\section{Training And Knowledge Advancement For Greening Economies}

Labor markets will be affected by green economy. Some jobs will be substituted in the process of shifting from fossil fuels to renewable or from land filling and waste incineration to recycling some jobs will be altogether lost without direct replacement when production of certain products is banned by regulation. Additional jobs will be created, e.g., in the manufacture of new products or offering of new services in a proenvironment economy; and a number of existing jobs will be transformed with new competencies, such as those of plumbers, electricians and metal and construction workers as corporation adopt greening measures or build new buildings with energy-efficient equipment. Thus, a greening economy would require new training and retraining of the workforce to adopt new production process. As fossil fuel-based industries move toward greening, a number of workers may lose their jobs or could be at risk of losing jobs unless their skills are updated and retained.

The overarching policy challenge is how best to coordinate employment and skills development policies with environmental and sector policies for more sustainable development and low carbon economics. Skills development is a precondition for reaping the economics, carbon reducing and job opportunity benefits of low-carbon investments. The greening of jobs in industries with high technology and innovation content would rely on specialist knowledge, especially in the fields such as sciences, technology, engineering and 
mathematics (STEM). Close cooperation between education institutions, governments and the business community will be essential to ensure that education equips individuals with the skills necessary to be competitive in a greening job market (International Organization of Employers, 2010).

A study by the European Centre for the Development of Vocational Training (Cedefop, 2010) revealed none of the European Union member States, with the exception of France, had put in place integral skills response strategies as part of their environmental and green growth strategies. Many of the green industries in Asia are currently fragmented. University offerings lack cross-disciplinary breadth and faculty needed to train future workers in the technical, economics, social and managerial challenges associated with green industry development. Green economies and green jobs are also spurred by innovations. In addition to technical training, there is a need to facilitate entrepreneurship training, business incubation services and access to finance. This can help low-income countries to leapfrog on the technology spectrum and turn innovation for a green economy into successful business models.

In addition to skills training, addressing a wider range of institutions regulatory and quality assurances issues will help Asia to benchmark its progress against well-articulated standards. For example, the Leadership in Energy and Environmental Design (LEED) Green Building Rating System is a third-party certification program and the nationally accepted benchmark for the design, construction and operation of high performance green buildings. LEED provides building owners and operators with the tools they need to have an immediate and measureable impact on their buildings performance. An Asia Pacific Certification is on the cards for green buildings. Further work in this domain will establish Asia's leadership in green growth.

Green jobs have great potential, however, they need not automatically be quality jobs, constituting "decent" work, i.e., with adequate wages, safe working conditions, job security, career prospects and worker rights. There are dangers of "green washing" where only nominal support to environmental goals actually provides very poor quality employment. An example could be poorquality electronics recycling which may give rise to employment in hazardous conditions. The use of unskilled labor in Biofuel and biomass production may give rise to numerous jobs but at subsistence wages and poor working conditions. In this case, green jobs do not constitute quality employment. Thus, it is important to ensure that green jobs are also "decent" jobs in pursuit of inclusive growth. For example, providing energy access to rural India and a distributed model of generating jobs that is not urban centric will support inclusive growth. There is need to consider active strategies in skills for green employment that take into account inclusive models. For examples, renewable energy models are fairly small scale and distributed-small-scale solar and wind projects which can give rise to the need for an extensive technical support services network, which can be addressed by skills training systems. There could well be a case here for multiple skilling techniques as it may become unfeasible to send a number of different experts to various rural locations.

\section{Greening TVET}

According to Fien and Guevara (2013), transitioning to a sustainable and low-carbon environment is a challenge to all parties. According to United Nations Inter Agency Working Group for the Decade of Education in Sustainable Development (DESD). The transition to green economy and sustainable society requires new laws and regulations, investment and institutional framework. The transition also requires TVET to engage more systematically in response to the changing job opportunities and skills needs that a green development agenda brings about (UNESCO, 2014). Greening economies and societies is closely related to creating green "human infrastructures" that possess the knowledge, skills, and attitudes to act as a catalyst of sustainable TVET transformation. Increasing TVET relevance is important by making changes in the sector corresponding to structural changes in the labor market. Mapping the relevant approaches to ensure that TVET systems are able to respond to skills needs for green development is critical. Unfortunately, orientating TVET to green economy is no easy task. The UNESCO report on TVET stated that a major constraint is to reorienteering TVET toward sustainable development (UNESCO, 2014). The equipment and materials required for training in a new technologies for training and more sustainable: changing chemicals, using sustainably produced and certified woods, installing equipment for training in solar and wind technologies; all require changes to TVET curriculum and facilities (UNESCO, 2014). TVET transformations suggest adapting skills training to changes in workplace practices. 
Greening TVET is a response to the pressing global issues with regards to sustainable development. It seeks to serve as a reference standards in supporting the implementation of TVET for sustainable development, as has been advocated by UNESCO and UNESCO-UNEVOC International Centre over the past decade. It is a holistic framework that presented improved opportunities for the TVET sector to support transition to a sustainable and low-carbon world. Climate change, the scarcity of resources and the effects of globalization are some of the drivers of the transition into green paradigm. TVET must respond to these challenges through the provision of green skills that meet the needs of the world of work and sustainable social transformation. Majumdar (2011) has suggested that a greening TVET should be built upon five strands of institutional operations to extend sustainable development principles in TVET institutions:

(1) Green campus - is based on philosophy of practicing what is preached. TVET institutions should employ sustainable management and efficient use of resources such as energy, water, waste, backed by policies and institutional frameworks.

(2) Green curriculum - refers to a systematic adaptation and revision of the curriculum and pedagogical / didactical methods, applications and approaches to effectively transfer skills that are relevant for work and life and meet the existing job profiles and standards in the labor market.

(3) Green community - involves extending sustainability principles and practices to create a sustainable impact on the community and societies.

(4) Green Research and Technology - means fostering of green technologies and innovations that promotes sustainability as well as the development of a research culture within institutions.

(5) Green culture - focuses on strengthening green values, ethical standards, attitudes and behaviors that respect green lifestyles.

The vibrant integration of sustainability into TVET is most effective when both enablers and drivers are working in synergy with each other. Education and training for greening economies and corporations needs to address all levels of education. At the basic education level, environmental education has an important role to play in creating awareness. The Johannesburg Sustainable Development Summit resulted in the announcement of a new decade - Education for Sustainable Development Decade from 2005 to 2015 - and this led to the incorporation of curricula on environment and sustainable development at the school level. Recent advances on climate change mitigation and adaptation efforts and the green growth have given rise to a range of needs at technical and vocational educations and at tertiary educational levels. In order to respond comprehensively to the needs of economies making the transition to green economies, education and training systems need to take and integrated view of potential opportunities and constraints for green initiatives. An integrated approach takes into account how the spectrum of competencies can be addressed at different levels of education. For effective greening initiatives, not only the main manufacturing company but the supply chain companies also need to adopt "greening" measures. Technology, materials management, processes and products all embody "green" elements.

\section{Greening In Asia}

According to Jagannathan (2013), green paradigm has prompted new employment opportunities. Asian countries should consider green economies as the mean for more and better jobs. A flagship report on green jobs by the United Nations Environment Program (2008) provided comprehensive insight on impact of a green economy on the word of work. The report asserts that rather than being a drag on growth would in fact help economies to create jobs that did not exist before and provide opportunities for government to bolster employment in new green sector and bring higher valueadded work for their youth. The future growth of green jobs would bring overall economic gains as well as a host of social and political advantages.

In order to attain sustainable development especially with regard to the environment, the substantial green stimulus packages that several Asian countries put in place in the aftermath of the economic crisis with significant "green" elements should continue. Evidently, dynamic Asian countries have increased public 
investment in green infrastructure - particularly in terms of public transport, low carbon energy production, smart electricity grids, energy efficiency of public buildings, and water and sanitation infrastructure. Employment opportunities were extensive in stimulus packages and measures to move towards a low-carbon economy were seen to help stimulate sustained employment (Anbumozhi \& Bauer 2010). Green era has the potential to employ workers with an even wider range of skills and experiences in a variety of sectors and contribute to a sustainable, lowcarbon economy. Economic sectors such as renewable energy and waste management could create new green jobs that did not exist before.

Asia Business Council (2009) has compiled a green jobs index that compared 13 Asia economies and the results suggest that the China possesses the most favorable conditions for green job creation, followed by Japan and India. South Korea, China, Malaysia, Singapore, Hong Kong, the Philippines, Indonesia, Thailand, and Vietnam also exhibit potential for green jobs at different levels. In India, a study finds that lowcarbon employment is one of the key factors of promoting the renewables sector (Global Climate Network, 2011). Solar power is more labor intensive than wind power and better able to meet India's requirement for small-scale, off-grid power. Using clean energy such as biomass, green transport, and public works in water and forest management are also attractive ways of achieving both employment and environmental objectives.

\section{Conclusion}

In the green paradigm, issues relating to education and training should be viewed in the overall context of education for sustainable development. However, "green" education and training are constrained by several factors such as slow responsiveness of education and training institutions in creating futuristic curricula for green jobs. To achieve sustainable development, Asia needs innovative plans and strategies to foster higher investment in quality human capital and green lifestyles. Mere cost advantages are no longer sufficient, a country should have a holistic strategy in terms of economic, education, social, environmental, and financial aspects. Appropriate and relevant policies and incentives should be put in place to amass talent pools especially those with creative and green mindset. In this article, I have argued that it is critical to transform the mindset and psyche of the Asians. As nations in Asia recalibrated their economies to reposition their survival in the global economy, some have invested in innovative-based competitiveness ability to generate new ideas, products, and services. There is clear evidence to show that TVET has played a key roles in enhancing green development. Education and training for greening economies and corporations needs to address all levels of education. At the basic education level, environmental education has an important role to play in creating awareness. Recent global agenda for green growth has given rise to a range of needs at technical and vocational educations and at tertiary educational levels. In order to respond comprehensively to the needs of economies making the transition to green economies, education and training systems need to take and integrated view of potential opportunities and constraints for green initiatives. An integrated approach takes into account how the spectrum of competencies can be addressed at different levels of education. This requires an effective green framework, policies and practices for creating a highly skilled and creative workforce and talent pool that is critical to achieving sustainable inclusive economic growth.

\section{References}

ADB (2011). Environmental program: Greening growth in Asia and the Pacific. Manila: ADB.

ADB (2012). Green growth, resources and resilience: Environmental sustainability in Asia and the Pacific. Manila: ADB.

Anbumozhi,V. \& Bauer, A. (2010). Impact of global recession on sustainable development and poverty linkages. Tokyo: ADB.

Ariff, M. (1991). The Malaysian economy: Pacific connections [South-East Asian Social Science Monographs]. Singapore: Oxford University Press. 
Asia Business Council (2009). Addressing Asia's new green jobs challenge. Hong Kong: Asia Business Council.

Cedefop (2010). Skills for green jobs. Luxembourg: Publications Office of the European Union.

Dixon, C. \& Drakakis-Smith, D. (1993). Economic and social decelopment in Pacific Asia. London:

Routledge.

Fien, J. \& Guevara, J.R. (2013). Skills for a green economy: Practice, possibilities, and prospects. In R. Maclean et al. (eds), Skills Development for Inclusive and Sustainable Growth in Developing Asia-Pacific. New York: Springer.

Global Climate Network (2011). Low carbon jobs in an interconnected world. London: GCN.

Islam, I., \& Chowdhury, A. (1997). Asian-Pacific economies: A survey. New York: Routledge.

ILO (2012). Working toward sustainable development: Opportunities for decent work and social inclusion in a green economy. Geneva: ILO.

International Organization of Employers (2010). IOE perspective on green jobs. Geneva: IOE.

Jagannathan, S. (2013). Education and skills in Asia: Responding to greening economies. In R. Maclean et al. (eds), Skills Development for Inclusive and Sustainable Growth in Developing Asia-Pacific. New York: Springer.

Majumdar, S. (2011). Developing a greening TVET framework (unpublished).

Maclean et al. (2013). Skills Development for Inclusive and Sustainable Growth in Developing Asia-Pacific. New York: Springer

Research Base (2014). Green skills for rural youth in South East Asia. Research Report for Plan International Indonesia, Mynmar, Thailand and Vietnam.

Saurbah, J. (2014). Greening of skills. Vietnam country report. Manila: ADB.

Strietska-llina et al. (2011). Skills for green jobs: A global view. Geneva: ILO.

UNESCO (2014). Shaping the future we want. Paris: UNESCO. 